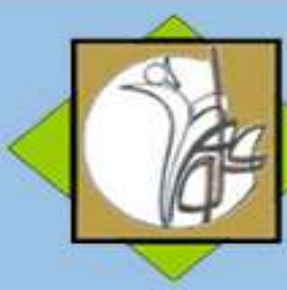

\author{
Research Article
}

\title{
The Effect of Internal / External Attention and Related / Unrelated on Quiet Eye Changes and Accuracy Free Throwing of Skilled Basketball Players
}

\author{
Hamid zahedi ${ }^{1}$, Foroghalsadat Tabatabaei ${ }^{2}$
}

1. Hamid zahedi, (Ph. D) NajafAbad branch, Islamic Azad University, NajafAbad, Iran.

2. Foroghalsadat Tabatabaei, (MA) Isfahan (Khorasgan) Branch, Islamic Azad University, Isfahan, Iran.

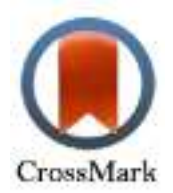

\section{ARTICLE INFO}

Received August 2018

Accepted November 2019

\section{KEYWORDS:}

Accuracy, Attentional Strategy, Basketball free throw, Gaz Behavior, Quiet Eye, Skilled Player

CITE:

zahedi, Tabatabaei. The Effect of Internal / External Attention and Related / Unrelated on Quiet Eye Changes and Accuracy Free Throwing of Skilled Basketball Players, Research in Sport Management \& Motor Behavior, 2021: 11(21):91-108

d. $10.52547 / J R S M .11 .21 .91$

\section{ABSTRACT}

Purpose: of this research was to compare the effects of internal/external and related/unrelated on Quiet eye changes and accuracy free throw of skilled male basketball players. Methodology: The statistical population of this research was all-male skilled basketball players of Esfahan city in 2017. Using purposeful sampling, 20 skilled basketball players (24/55 $\pm 2 / 25$ years) who were eligible to enter the research (using the Basketball Premier League players according to the test of the level of mastery of free throwing basketball) were selected. In order to measure the accuracy of basketball throwing, an eight-value scale was used. To measure the Quiet eye changes Eye-tracking was used. In order to analyze data using SPSS software using paired t-test and analysis of variance with repeated measures were used. Results: showed the impact of each of the strategies on the accuracy of free throws and Quiet eye changes in skilled basketball players. Also, unrelated external focus strategy compared with other strategies, further enhancing the accuracy of the basketball free throw and further increased the length of the Quiet eye of skilled basketball players Conclusion: It is recommended that coaches use an irrelevant external strategy to improve the performance and behavior of skilled athletes. 


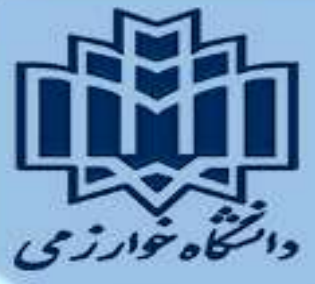

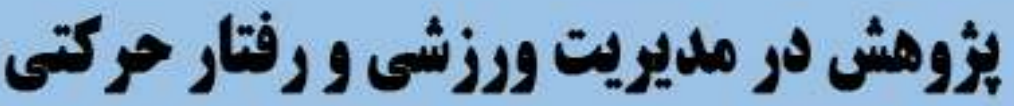

مقاله بُؤوهى

\section{اثر توجه درونى/بيرونى و مربوط/نامربوط بر تغييرات جششم ساكن و دقت يرتاب آزاد بسكتباليست هاى ماهر

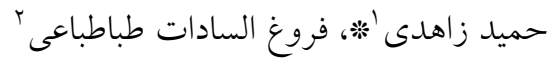

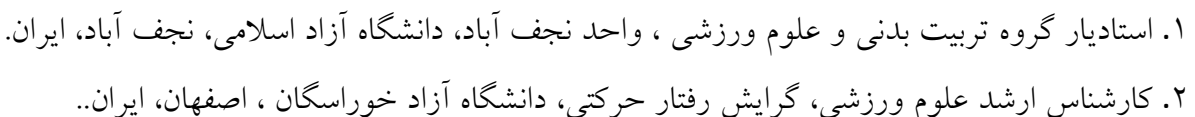

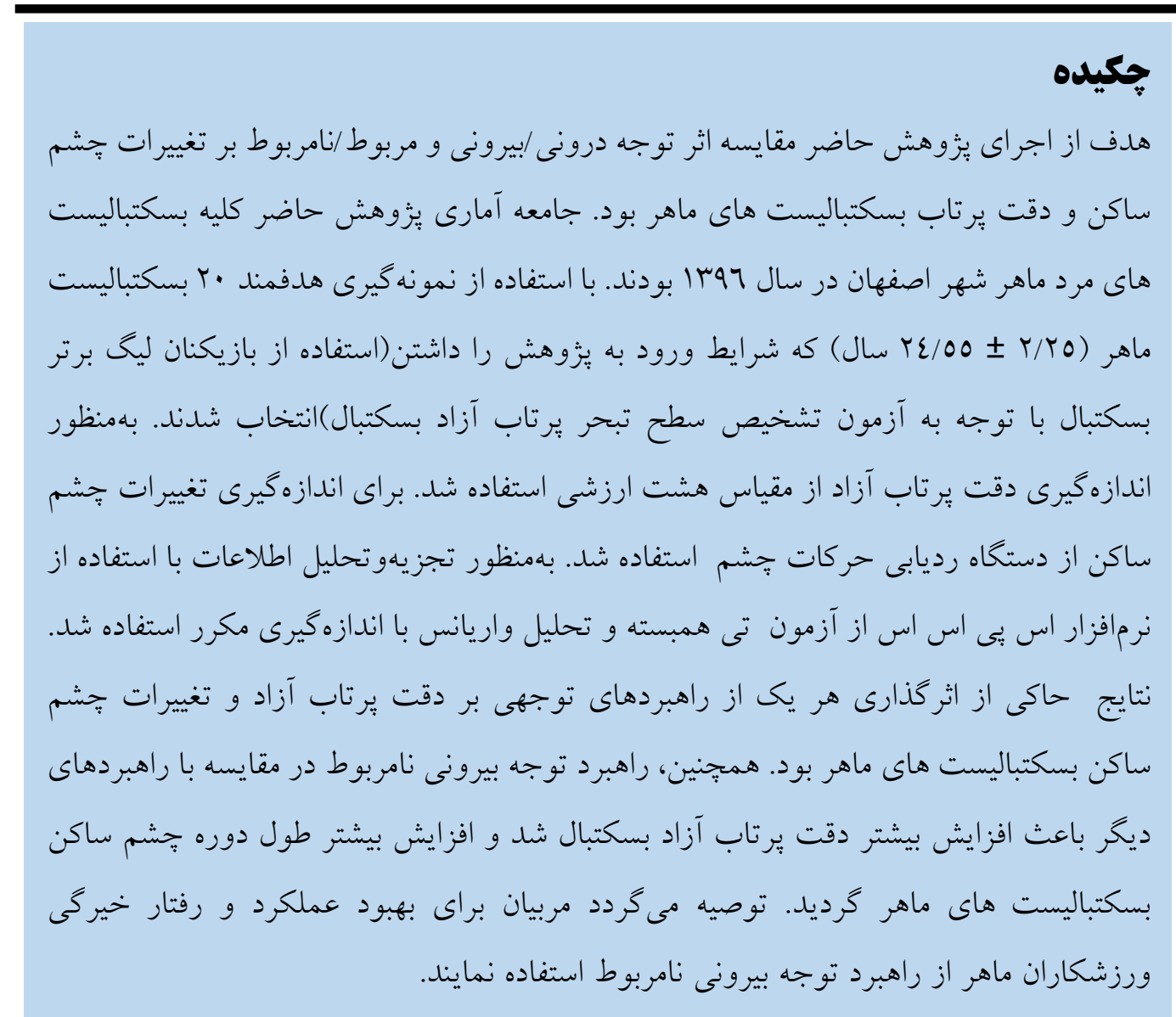

اطلاعات مقاله:

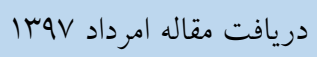

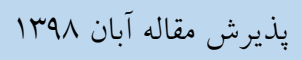

*قويسنده مسئول:

hamidzhd@yahoo.com

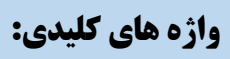

بازيكن ماهر، برتاب آزاد

بسكتبال، جشم ساكن، دقت،

رفتار خيرگى، راهبردهاى توجهى

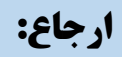

زاهدى، طباطباعى. اثر توجه

درونى/بيرونى و مربوط/نامربوط بر برى

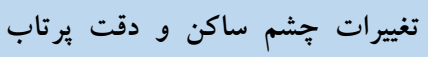

آزاد بسكتباليست هاى ماهر. يزّوهش

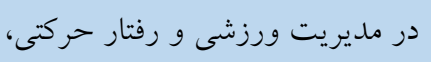

$91-1 \cdot 1:(Y)) 11: 1 \varepsilon$. 
در سه دهه كذشته، محققان بر اهميت مؤلفههاى ادراكى - شناختى براى رسيدن به اوج عملكرد تأكيد كردهاند (1). يكى از اين مؤلفهها كانون توجه' مىباشد. وولف (Y..V) كانون توجه را مكان تمركز ورزشكار در طى اجرا مىداند. تحقيقات تجربى در اين زمينه نشان مىدهد كه كانون توجه بر يادگيرى و اجراى مهارتهاى ورزشى تأثير مى گذارد(Y).

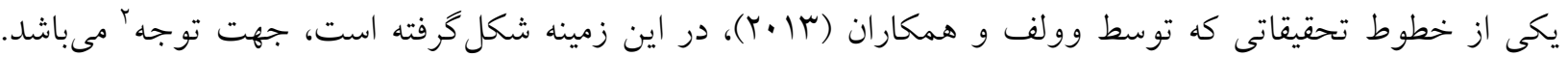
تحقيقات انجامشده در اين زمينه به بررسى كانون توجه درونى و بيرونى `مى يردازد(r).كانون توجه درونى، به موقعيتهايى اطلاق مى گردد كه فرد توجه خود را به بخشى از بدن و يا حركات خود در حين اجراى تكليف معطوف مى كند، در مقابل، كانون توجه بيرونى، به مواقعى اطلاق مى گردد كه فرد، توجه خود را به اثرات و نتايج حركت خود در محيط معطوف

مى سازد (r). كروهى از تحقيقات بر مزاياى توجه بيرونى نسبت به توجه درونى در افراد مبتدى و ماهر تأكيددارند (r-O) و در مقابل، گروه ديخرى از تحقيقات، بر مزاياى توجه مربوط به تكليف صرفنظر از درونى و يا بيرونى بودن آنها در افراد مبتدى و همجنين مزاياى توجه نامربوط در افراد ماهر تأكيددارند(7-A). اكرجه نتايج يزوهش هايى به برترى كانون توجه درونى نسبت به كانون توجه بيرونى با توجه به سطح مهارت افراد تأكيد داشتهاند(V-9) ، اما عمده تحقيقات انجام گرفته در اين زمينه تحقيقاتى، بر مزاياى كانون توجه بيرونى نسبت به شرايط

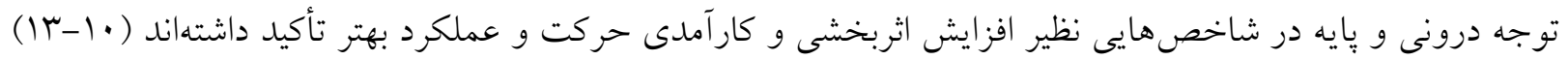

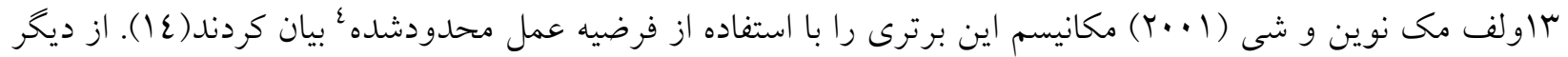
مكانيسمها براى بررسى اين برترى مىتوان به نظريه كد كذارى مشترى يرينز ( • (199) اشاره نمود كه بحث اصلى آن آن اين

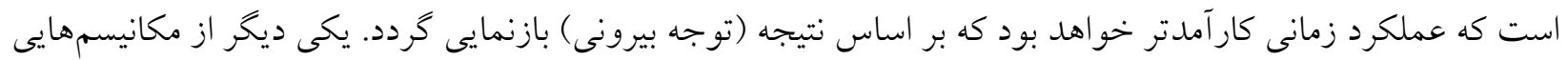
كه توسط طرفداران سيستمهاى يويا` شكل گرفته است، رويكرد قيود محور `مىباشد (10).

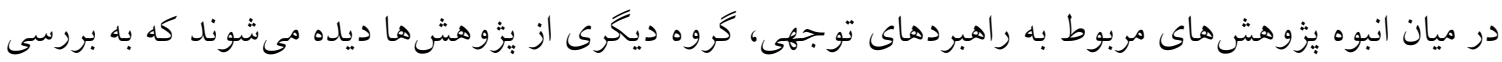
جّكونگى تأثير گذارى توجه بر عملكرد حركتى با رويكرد توجه معطوف به جنبه هاى مرتبط به تكليف (توجه مربوط به

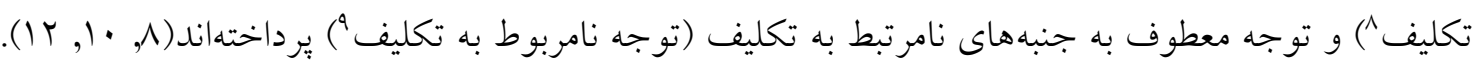

\footnotetext{
1. focus attention

2. Attentional direction

3 . internal \& external attentional focus

${ }^{4}$. constrained action hypothesis

${ }^{5}$. Prinz's theory of common coding

${ }^{6}$. dynamic systems

${ }^{7}$. constraints-led perspective

${ }^{8}$. task relevant attention

${ }^{9}$. task irrelevant attention
}

https://jrsm.khu.ac.ir/ 
راهبردهاى توجهى تكليف محور، به شرايطى اطلاق مى گردد كه اجراكننده توجه خود را بهطور هشيار بر جنبهاى مربوط به تكليف در حال اجرا معطوف مى سازد، در مقابل، در شرايط نامربوط به تكليف، اجراكننده توجه خود را بر جنبه هاى محيطى و نامربوط به تكليف سوق مى دهد.

بر اساس نظريه ارزيابى آشكار "'، اثركذارى راهبردهاى توجهى ممكن است براى ياد گيرندهاى ماهر و مبتدى به دليل تفاوت سطح خودكارى متفاوت باشد(7) ، بهعبارتديخر، نوآموزان تمايل به كنترل هشيارانه و ارزيابى كامبه كام مهارتهاى حركتى جديد خوددارند، درحالى كه، اجراى مهارتهاى حركتى در افراد ماهر و نخبه، كمتر در فرايندهاى كنترل هشيار و لحظهاى در گير شده و بهصورت خودكار و نا هشيارانه انجام مى گيرد(9). به همين دليل، برخى از محققين بر اين باورند كه راهبردهاى توجهى معطوف به تكليف بهواسطه دركير كردن نوآموزان در ارزيابىهاى كامبه كام و كتترل هشيارانه مهارت حركتى منجر به بهبود عملكرد مى گردد (IV).

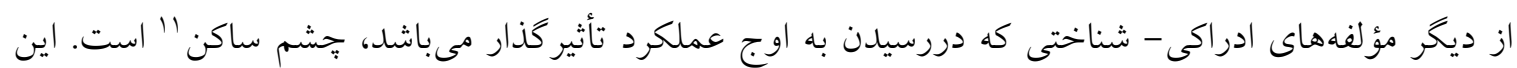

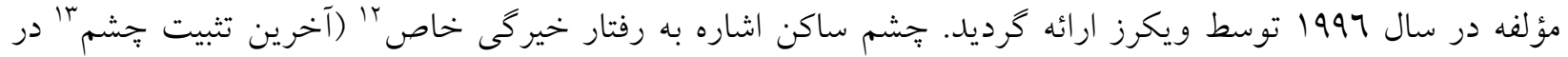
زمانى كمتر از · • ( هزارم ثانيه قبل از اجراى حركت) در طى اعمال ورزشى دارد (1/). ويكرز بيان كرد كه آخرين تثبيت

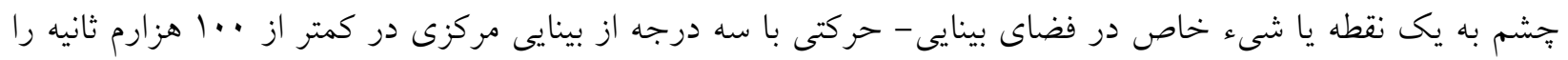

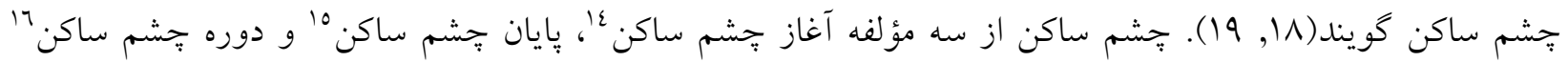
تشكيل شده است. به شروع آخرين تثبيت شدن بر روى هدف موردنظر، آغاز جشم ساكن گويند. زمانى كه آخرين تثبيت شدن بر روى هدف موردنظر منحرف مى گردد بهعنوان بايان جشم ساكن شناخته مىشود. به فاصله زمانى بين آغاز و پِايان

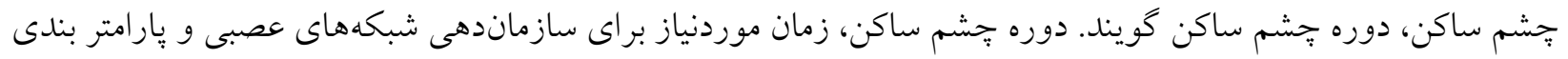
بينايى كه مسئول كنترل حركات دقيق است را نشان مى دهد. در طول اين دوره اطلاعات حسى با مكانيسمهاى لازم براى طرحريزى (برنامهريزى) و كنترل در لحظه براى ايجاد باسخ حركتى مناسب تركيب مى شود. هر دو عامل شروع زودتر و

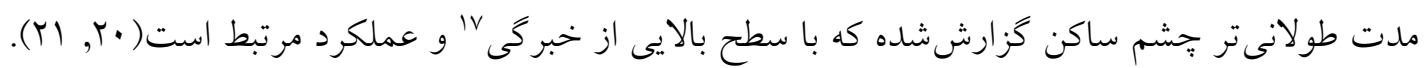
نتايج نشان داده كه هم كانون توجه بيرونى و هم جشم ساكن با سطح بالايى از عملكرد و خبركى ارتباط دارند(1/). علت

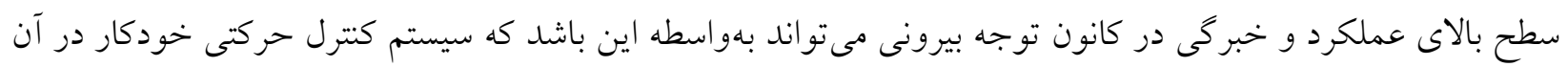
دخيل مى باشد (YY). در مورد مكانيسمهاى تعيين كننده جشم ساكن در سطح بالاى عملكرد و خبركى، به نظر مىرسد كه

\footnotetext{
${ }^{10}$. explicit monitoring theory

11. Quiet eye

${ }^{12}$. specific gaze behavior

${ }^{13}$. eye fixation

14. Quiet eye onset

${ }^{15}$. quiet eye offset

${ }^{16}$. quiet eye period

17. Expertise
}

https://jrsm.khu.ac.ir/ 
يردازش شناختى در اين دوره تعيين كننده باشد. ويكرز (1997) بيان مى كند كه در طول دوره جشم ساكن، بيش برنامهريزى يارامترهاى حركت اتفاق مىافتد. بنابراين، جشم ساكن بايد در برابر تفكرات اضافى بهوسيله هدايت توجه بهصورت بيرونى حفظ گردد(ب). بر اساس اين نتايج، از جشم ساكن بهعنوان يكى از مؤلفههاى بهينه كانون توجه ديدارى ياد مىشود (19). بر اساس اين مفروضه، تحقيقات جديد در اين زمينه به بررسى همزمان اين دو مؤلفه بر عملكرد حركتى

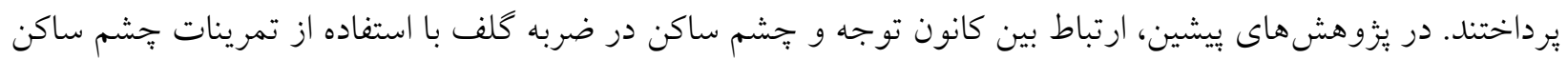
در ورزشكاران مبتدى و ماهر بررسىشده و نتايج نشان داده كه دوره جشم ساكن بهعنوان يك تكنيك كاربردى براى هدايت كانون بيرونى توجه ديدارى مىباشد. بنابراين تمرينات جشم ساكن بهطور بهينه بر توجه افراد تمركز مىنمايد و

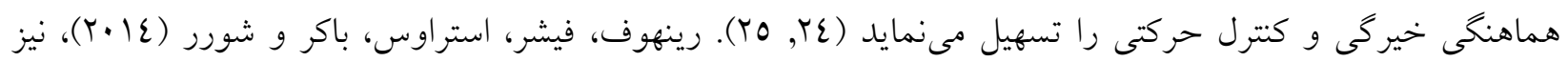
دريكى از اولين مطالعات در اين زمينه به بررسى تعامل بين كانون توجه و جشم ساكن در بسكتباليستها با سطوح متفاوت

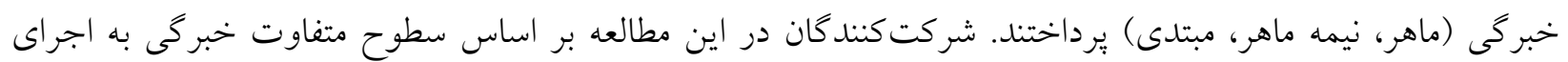

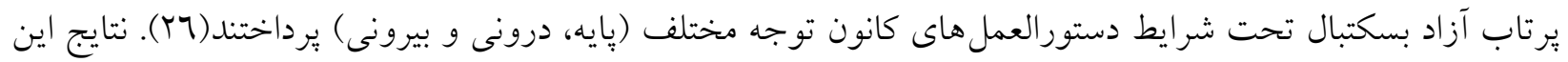
مطالعه نشان داد كه در سطوح مختلف خبركى ميزان دقت يرتاب و دوره جّشم ساكن تحت شرايط كانون توجه بيرونى كاهش مى يافت. اين يافته مغاير با برترى كانون توجه بيرونى نسبت به كانون توجه درونى بود. محققين اين بزوهش از

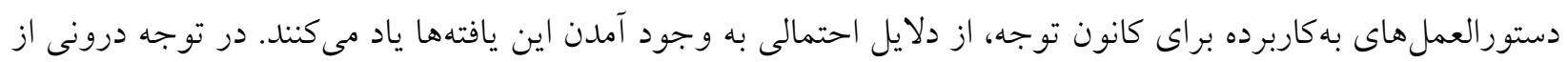
شركتكنندكان خواستهشده بود كه به دست خود تمركز نمايند كه اين عبارت مطابق با بررسىهاى ييشين كانون توجه،

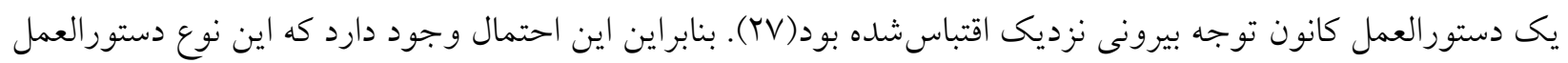
باعث به وجود آمدن نتيجه متناقض با ديدكاهها و مطالعات با برترى كانون توجه بيرونى باشد. كلاستر من، كردل و هاسنر (ع (Y. (Y) در مطالعهاى ديخر به تعامل بين كانون توجه و جشم ساكن در ضربه كلف برداختند. نتايج اين مطالعه نشان داد كه در سطوح خبركى متفاوت، شركت كنند گان با تمركز بر نتيجه حركت (كانون توجه بيرونى) خطاى كمترى در تكليف موردنظر داشتند ، همجنين در سطوح خبر گیى متفاوت، ميزان دوره جّشم ساكن در تكاليف مربوط به نتيجه حركت (بيرونى) بيشتر بود) (YN).

در ميان يزوهشهاى مربوط به راهبردهاى توجهى، گروه ديخرى از يزوهشها ديده مى شوند كه به بررسى جֶ) نكى تأثير گذارى توجه بر عملكرد حركتى با رويكرد توجه معطوف به جنبههاى مرتبط به تكليف (توجه مربوط به تكليف^) و توجه معطوف به جنبههاى نامرتبط به تكليف (توجه نامربوط به تكليف هُ) يرداخته اند( •(1). راهبردهاى توجهى تكليف محور، به شرايطى اطلاق مى كردد كه اجراكننده توجه خود را بطور هشيار بر جنبه

18 . task relevant attention

19. task irrelevant attention

https://jrsm.khu.ac.ir/ 
هاى مربوط به تكليف در حال اجرا معطوف مى سازد، در مقابل، در شرايط نامربوط به تكليف، اجر اكننده توجه خود را بر جنبه هاى محيطى و نامربوط به تكليف سوق مى دهد. براى مثال، در مهارتى نظير يرتاب آزاد بسكتبال، مربى مى تواند به كمك راهبردهاى مختلف توجهى، توجه ورزشكار را بر جنبه هاى مربوط به تكليف، نظير حركت دست ها و يا توبٍ (توجه مربوط به تكليف) و يا توجه به صداى تماشاكران در حين اجراى مهارت (توجه نامربوط به تكليف) سوق دهد. بر اساس يافتهاى يزوهشهاى انجام شده در اين خط مطالعاتى، افراد ماهر در شرايط توجه نامربوط بهترين عملكرد خود را به نمايش مى كذارند و در مقابل، افراد مبتدى در شرايط توجهى مربوط به تكليف بهتر عمل مىكنند(9). بر اساس نظريه ارزيابى آشكار •(Yq) ، اثر كذارى راهبردهاى توجهى ممكن است براى ياد گيرندهاى ماهر و مبتدى به دليل تفاوت سطح خودكارى متفاوت باشد(7 (1) ، به عبارت ديخر، نو آموزان تمايل به كنترل هشيارانه و ارزيابى كام به كام مهارت هاى حركتى جديد خود دارند، در حالى كه، اجراى مهارت هاى حركتى در افراد ماهر ، كمتر در فرايندهاى كنترل هشيارانه و لحظهاى دركير شده و بصورت خودكار و ناهشيار انه انجام مى گيرد(9). به همين خاطر، برخى از محققين بر اين باورند كه راهبردهاى توجهى معطوف به تكليف به واسطه درگير كردن نوآموزان در ارزيابى هاى كام به كام و كتترل هشيارانه مهارت حركتى منجر به بهبود عملكرد مى كردد(IV).

با توجه به مطالب ارائه شده محقق در بي بِاسخ به اين سؤال است كه آيا راهبردهاى مختلف توجهى بر تغييرات جشم

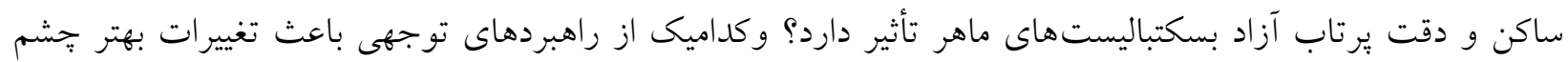
ساكن و دقت يرتاب آزاد بسكتباليستهاى ماهر مىشود؟ لذا، هدف از اجراى بُزوهش حاضر بررسى اثر تغييرات جشم ساكن در شرايط مختلف توجهى در اجراى دقت يرتاب آزاد مردان بسكتباليست ماهر مىباشد.

\section{روش شناسى}

يزوهش حاضر از نوع تحقيقات نيمه تجربى است. همجنين با توجه به طول زمان اجراى تحقيق از نوع مقطعى و به لحاظ استفاده از نتايج بهدستآمده، كاربردى مى باشد. جامعه آمارى يُزوهش حاضر را كليه بسكتباليستهاى مرد ماهر شهر اصفهان در سال 97ها تشكيل داد. با استفاده از نمونه كيرى هدفمند ·r بسكتباليست ماهر كه شرايط ورود به يزوهش را داشتند(سابقه حضور حداقل 0 سال در تيم

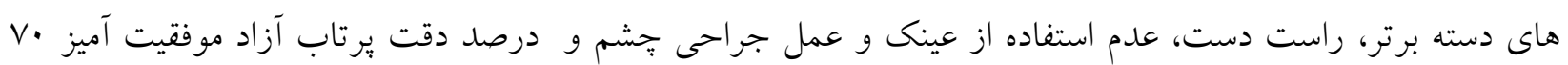
درصدانتخاب شدند.

\footnotetext{
${ }^{20}$. explicit monitoring theory
}

https://jrsm.khu.ac.ir/ 
بهمنظور اندازه كيرى دقت يرتاب آزاد افراد شركت كننده از آزمون يرتاب آزاد بسكتبال استفاده شد. در اين روش برتابك كننده

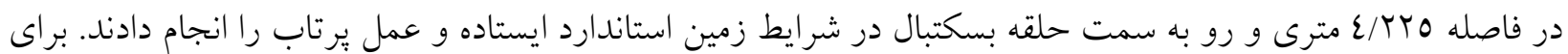
سنجش دقت يرتابهاى آزاد از مقياس هشت ارزشى استفاده شد (سT). در اين روش اندازه كيرى دقت برتاب آزاد، عدم برخورد توب با حلقه و تخته يك امتياز، برخورد آرام توبٍ با لبه خارجى حلقه دو امتياز، برخورد شديد توبٍ با لبه

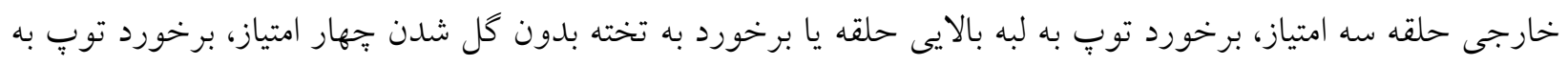

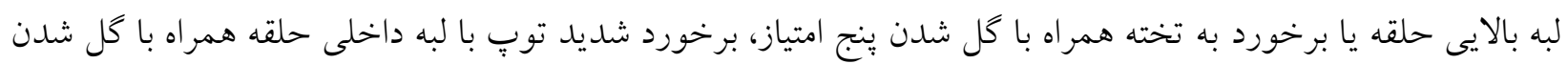

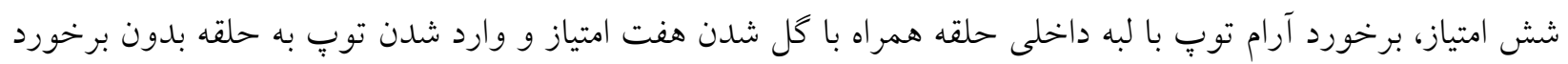
با حلقه هشت امتياز داشت(T).

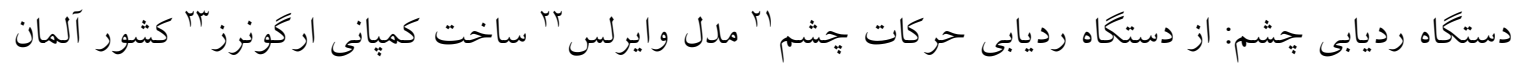
كه نقطه خيركى در هرلحظه را با فركانس •9 هرتز ثبت مى كند، جهت اندازه خيرى و رديابى جشم استفاده شد. اين سيستم

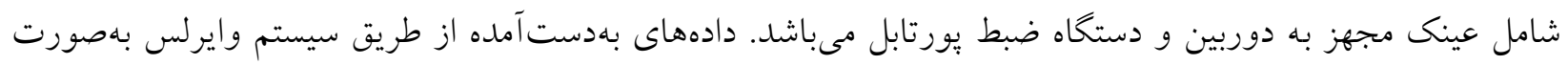
نوار ويدئوئى به كامييوتر داراى قابليت اتصال فرستاده شد. بهمنظور ثبت حركات و تغييرات جشم از نرمافزار DLab و سيستم يردازش اطلاعات ساخت اين كميانى استفاده شد. اين نرمافزار سه مؤلفه جشم ساكن را مشخص مى كند: آغاز

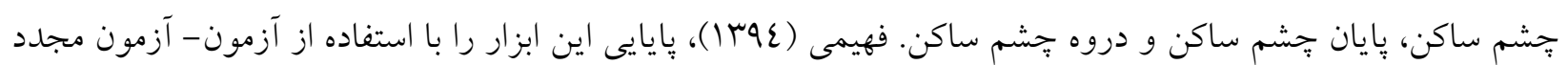

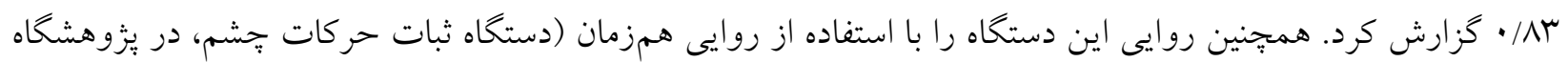

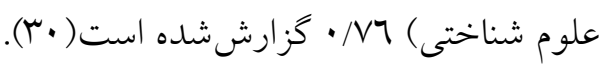

\section{روش اجرا}

يس از انتخاب شركت كنند گان و تكميل فرم رضايت توسط آنان، اهداف تحقيق و نحوه اجرا به آنان توضيح داده شد. جهت آشنايى و تطبيق شركت كنندكان با دستخاه ثبت حركات جشم و كنترل اثر استفاده از دستخاه بيست دقيقه قبل از اجراى تكليف عينك دستخاه روى جشم افراد قرار گرفت و با توضيحات ارائه شده از سوى محقق سعى شد تمام توجه فرد فقط به دستور العمل هاى محقق منتهى شود و بعد از كسب اطمينان نسبى از اينكه شركت كننده با استفاده از عينك

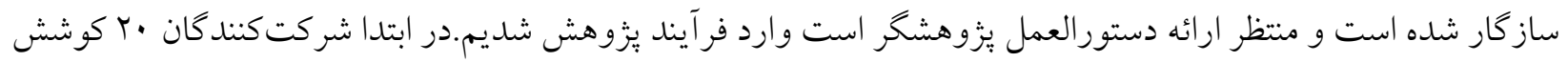

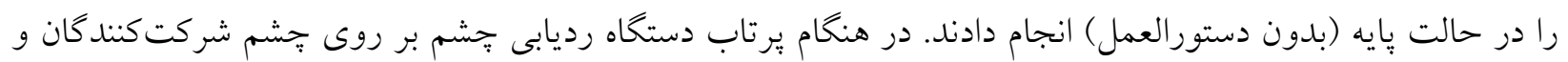

\footnotetext{
21. Eye tracking

22. Dikablis Professional Wireless

23. ERGONEERS
}

https://jrsm.khu.ac.ir/ 


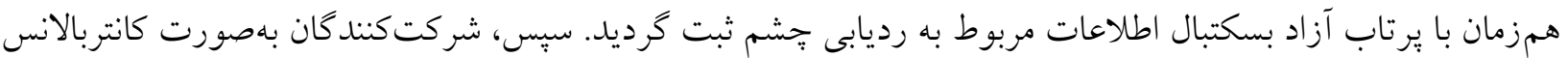
(براى حذف اثر ترتيب) درمجموع •^ كوشش تمرينى را در جهار شرايط راهبردهاى توجهى بيرونى - مربوط، بيرونى -

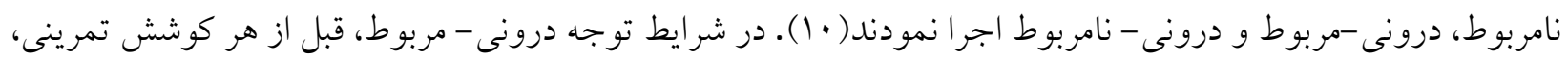
از شركت كند كان درخواست شد تا ضمن اين كه سعى بر كسب حداكثر امتياز مهارت يرتاب آزاد بسكتبال دارند، بهطور ذهنى بر حركت فلكشن مج دست يرتابكننده خود تمركز نمايند. در شرايط توجه بيرونى - مربوط، قبل از هر كوشش تمرينى، از شركت كنند كان درخواست شد ضمن اينكه سعى بر كسب حداكثر امتياز دارند، بهطور ذهنى بر لبه حلقه

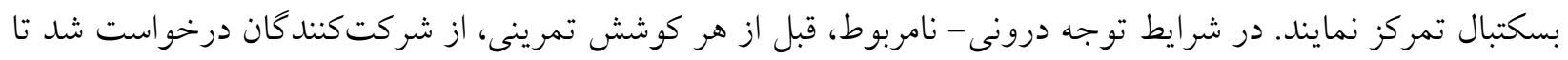
ضمن اين كه سعى بر كسب حداكثر امتياز دارند، بهطور ذهنى بر روى عمل دم و يا بازدم تنفس خود تمركز نمايند و پِس از هر كوشش در مورد آن قضاوت كنند. در شرايط توجه بيرونى - نامربوط، قبل از هر كوشش تمرينى، از شركتكنندگان درخواست شد تا ضمن اينكه سعى بر كسب حداكثر امتياز دارند، بهطور ذهنى بر ارائه محرك شنيدارى زير يا بم كه بهطور همزمان با تكليف يرتاب آزاد بسكتبال و به شكل تصادفى توسط برنامه طراحىشده در محيط نرمافزار متلب

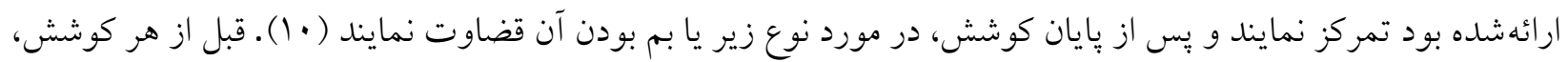
شركت كنند كان راهبردهاى توجهى مرتبط با شرايط خود را كه بر روى بر گهاى نوشتهشده بود با صداى بلند باز گو كردند،

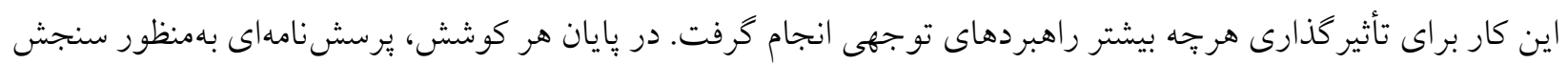

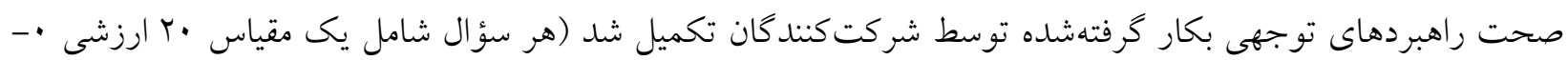

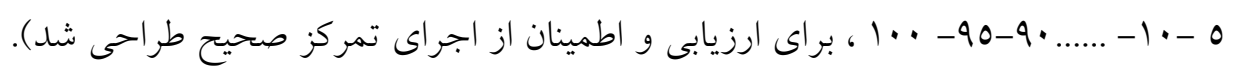

در وضعيت راهبرد توجهى بيرونى - نامربوط، از شركت كنند كان درخواست شد تا در حين انجام تكليف اوليه، به فركانسى شامل دو تون زيروبم كه بهصورت تصادفى ارائه مىشد، تمركز نمايند و در پايان كوشش به اين سؤ ال كه در حين اجراى كوشش مربوط به تكليف اوليه، جه صدايى شنيدهايد، ياسخ دهند. در گروه راهبردهاى توجهى درونىنامربوط، از شركت كندكان درخواست شد تا در حين انجام تكليف اوليه، به عمل دم و بازدمشان تمركز نموده و در پايان قضاوت كنند كه در حين اجراى تكليف اوليه، كداميك از اعمال دم و يا بازدم را انجام دادهاند. دليل انتخاب اين نوع تكليف ثانويه قابليت اجراى همزمان آن با تكليف اوليه يرتاب آزاد بسكتبال بدون اختلال و يا تغيير در مكانيسمهاى باى

تكليف اوليه بود (•) (1).

\section{روش آمارى}

بهمنظور تجزيهوتحليل اطلاعات، از روشهاى آمار توصيفى براى محاسبه شاخصهاى مركزى و براكندگى استفاده شد. در بخش آمار استنباطى يُ إز تائيد يِشفرض هاى لازم، از آزمون تى وابسته براى نشان دادن اثر هر يك از

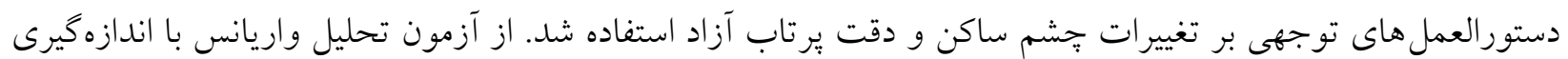


تكرارى براى مقايسه نوع دستورالعمل هاى مختلف توجهى استفاده شد. تجزيهو تحليل دادهها با استفاده از نرمافزار SPSS نسخه ا Y در سطح معنادارى كمتر از ينجصدم انجام شد.

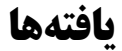

جدول ( ) شاخصهاى آمارى جمعيت شناختى شركت كندكان

\begin{tabular}{|c|c|c|c|}
\hline انحر اف معيار & ميانخين & تعداد & متغير \\
\hline T/TO & $r \varepsilon / 00$ & r. & سن (سال) \\
\hline $0 / . Y$ & $191 / 9$. & $r$. & قد (سانتيمتر) \\
\hline $0 / .1$ & $9 V / 9$. & r. & وزن (كيلوكرم) \\
\hline
\end{tabular}

جدول (Y) ميانكين و انحراف معيار متغيرهاى يزوهش

\begin{tabular}{|c|c|c|c|}
\hline انحراف معيار & ميانخين & مرحله & متغير \\
\hline 1/or & $\varepsilon / .0$ & حالت بايه & \multirow{5}{*}{ دقت يرتاب } \\
\hline$r / \cdot 1$ & $0 / 20$ & كانون توجه درونى مربوط & \\
\hline$T / T)$ & $0 / \wedge$. & كانون توجه درونى نامربوط & \\
\hline $1 / 77$ & $7 / 00$ & كانون توجه بيرونى مربوط & \\
\hline $1 / r \varepsilon$ & vro & كانون توجه بيرونى نامربوط & \\
\hline$\varepsilon 9 / \pi\urcorner$ & $11 \cdot r / \Lambda$ & حالت بايه & \multirow{5}{*}{ جشم ساكن (برحسب ميلىثانيه) } \\
\hline$T r / \mu r$ & $\| \varepsilon r / \varepsilon$ & كانون توجه درونى مربوط & \\
\hline $0 r / 00$ & $117 \cdot / r$ & كانون توجه درونى نامربوط & \\
\hline $01 / \cdot \varepsilon$ & $11 \mathrm{AV} / 7$ & كانون توجه بيرونى مربوط & \\
\hline$r q / \varepsilon$. & $|r| V / \cdot$ & كانون توجه بيرونى نامربوط & \\
\hline
\end{tabular}

همانكونه كه نتايج جدول دو نشان مىدهد بهترين امتياز دقت برتاب آزاد در حالت اتخاذ كانون توجه بيرونى

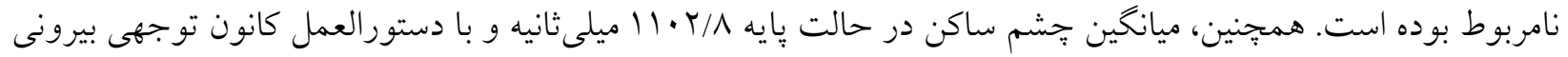

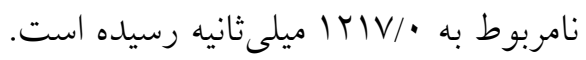


يافته هاى حاصل از اثر نوع كانون توجه بر دقت يرتاب آزاد بسكتبال و تغييرات جشم ساكن با عنايت به نوع كانون توجه اتخاذشده در جدول شماره سه ارائهشده است.

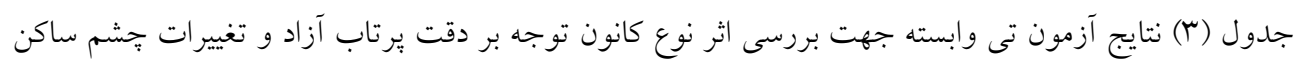

\begin{tabular}{|c|c|c|c|}
\hline \multicolumn{2}{|c|}{ نتيجه } & مرحله & موقعيت \\
\hline$t=-0 / 00$ & $p=\cdot / \cdots 1$ & توجه بيرونى مربوط & \multirow{4}{*}{ دقت } \\
\hline$t=-V / q$. & $p=\cdot / \cdots \cdot 1$ & توجه بيرونى نامربوط & \\
\hline$t=-r / I r$ & $p=\cdot / \cdot \varepsilon V$ & توجه درونى مربوط & \\
\hline$t=-\Gamma / \Gamma)$ & $p=\cdot / \cdot \varepsilon$ & توجه درونى نامربوط & \\
\hline$t=-\varepsilon / \Lambda \Lambda$ & $\mathrm{p}=\cdot / \cdots \cdot 1$ & توجه بيرونى مربوط & \multirow{4}{*}{ جششم ساكن } \\
\hline$t=-V / 07$ & $p=\cdot / \cdots \cdot 1$ & توجه بيرونى نامربوط & \\
\hline$t=-0 / \cdot V$ & $p=\cdot / \cdots \cdot$ & توجه درونى نامربوط & \\
\hline$t=-r / \Gamma$. & $p=\cdot / \cdot r$ & توجه درونى مربوط & \\
\hline
\end{tabular}

اطلاعات ارائهشده در جدول فوق نشان مىدهد اثر نوع كانون توجه (درونى - بيرونى/مربوط-نامربوط) استفادهده بر دقت يرتاب آزاد بسكتبال و تغييرات جشم ساكن اثر كذار بوده است و به لحاظ آمارى معنادار مىباشد.

جدول (ع) آزمون اندازههاى تكرارى در مقايسه دستور العمل هاى مختلف توجهى بر دقت يرتاب آزاد

\begin{tabular}{|c|c|c|c|c|c|c|c|}
\hline مجذور اتا & سطح معنادارى & آماره آزمون & ميانكين مربعات & درجه آزادى & مجموع مربعات & منبع تغيير & \\
\hline \multirow[t]{2}{*}{ • } & \multirow[t]{2}{*}{$\cdot \cdots \cdot 1$} & \multirow[t]{2}{*}{ 9/0r } & $r \cdot / v 1$ & $\varepsilon$ & ITY/AE & شمرين & \multirow[t]{2}{*}{ داخل كروهى } \\
\hline & & & $r / T r$ & vi & YELN/ & خططا & \\
\hline
\end{tabular}

اطلاعات حاصل از آزمون اندازهكيرى تكرارى ارائهشده در جدول شماره جهار نشان داد اتخاذ نوع كانون بر دقت يرتاب آزاد اثر كذار بوده و به لحاظ آمارى تفاوت در سطح كمتر از ينجصدم معنادار مىباشد.

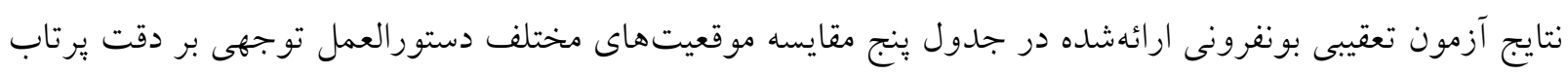
آزاد بسكتبال را ارائه كرده است. 
جدول (b) نتايج آزمون تعقيبى بونفرونى براى مقايسه دقت دستورالعمل هاى مختلف توجهى

\begin{tabular}{|c|c|c|c|c|}
\hline سطح معنادارى & خطاى معيار & اختلاف ميانگين & موقعيت r & موقعيت 1 \\
\hline$\cdot / 49$ & $\cdot 190$ & $-1 / 4$ & درونى مربوط & \multirow{4}{*}{ حالت پايه } \\
\hline$\cdot / \cdot r$ & $\cdot / D T$ & $-1 / V \Delta$ & درونى نامربوط & \\
\hline$\cdot 1 \cdot \cdots 1$ & $\cdot / \mathbb{A} \Delta$ & $-r / \Delta \cdot$ & بيرونى مربوط & \\
\hline$\cdot 1 \cdot \cdots 1$ & $\cdot|f|$ & - & بيرونى نامربوط & \\
\hline $1 / \cdots$ & $\cdot / V \Delta$ & $-\cdot / r \Delta$ & درونى نامربوط & \multirow{3}{*}{ درونى مربوط } \\
\hline$\cdot / F \Delta$ & .101 & $-1 / 1$ & بيرونى مربوط & \\
\hline$\cdot 1 \cdot r$ & $\cdot / \Delta F$ & $-1 / 9$ & بيرونى نامربوط & \\
\hline $1 / \cdots$ & .194 & $-\cdot / V \theta$ & بيرونى مربوط & \multirow{2}{*}{ درونى نامربوط } \\
\hline .111 & $\cdot 10 \Delta$ & $-1 / \Delta \Delta$ & بيرونى نامربوط & \\
\hline $1 / \cdots$ & . $/ \Delta T$ & $-\cdot / \Lambda$ & بيرونى نامربوط & بيرونى مربوط \\
\hline
\end{tabular}

در جدول شماره شش و هفت به ترتيب نتايج آزمون اندازهيرى تكرارى و آزمون تعقيبى بونفرونى حاصل از اثر اتخاذ نوع كانون توجه بر تغييرات جشم ساكن گزارش جدول (9) آزمون اندازهاى تكرارى در مقايسه دستورالعملهاى مختلف توجهى بر تغييرات جشم ساكن

\begin{tabular}{|c|c|c|c|c|c|c|c|}
\hline مجذور اتا & معنادارى سطح & آزماره & مريعانخين & آزادى & مربعوع & تغنيع & \\
\hline \multirow[t]{2}{*}{.$/ F T F$} & \multirow[t]{2}{*}{$\cdot 1 \cdot \cdots 1$} & \multirow[t]{2}{*}{$1 \pi / 91$} & $r V V \cdot V / \Lambda r$ & f & $|Q \cdot \Lambda r| / r F$ & شر شرين & \multirow{2}{*}{ دروهى } \\
\hline & & & rৎ৭९/Fr & Ve & r. & خطا & \\
\hline
\end{tabular}

نتايج حاصل از جدول شماره شش نشان داد اتخاذ نوع كانون توجه بر تغييرات جشم ساكن اثر معنادار داشته 
جدول (V) نتايج آزمون تعقيبى بونفرونى براى مقايسه تغييرات خشم ساكن دستور العملهاى مختلف توجهى

\begin{tabular}{|c|c|c|c|c|}
\hline سطح معنادارى & خطاى معيار & اختلاف ميانخين & موقعيت r & موقعيت 1 \\
\hline •/MT & $1 V / 09$ & $-F \cdot \mid \Delta \Delta$ & درونى مربوط & \multirow{4}{*}{ حالت پايه } \\
\hline$\cdot 1 \cdot \cdot 1$ & $11 / \mu \cdot$ & $-\Delta V / \Gamma \Delta$ & درونى نامربوط & \\
\hline$\cdot 1 \cdot \cdot 1$ & $I V / T F$ & $-\Lambda F / \Lambda$. & بيرونى مربوط & \\
\hline$\cdot 1 \cdot \cdots 1$ & $10 / 1$. & $-11 F / T \Delta$ & بيرونى نامربوط & \\
\hline $1 / \cdot$ & IV/GY & -1911. & درونى نامربوط & \multirow{3}{*}{ درونى مربوط } \\
\hline .119 & $I V / T \Lambda$ & $-F F / T \Delta$ & بيرونى مربوط & \\
\hline$\cdot / \cdot r$ & $\mid 9 / V 1$ & $-V \mu / V \cdot$ & بيرونى نامربوط & \\
\hline $1 / \cdot \cdot$ & IN/gr & $-Y V / F D$ & بيرونى مربوط & \multirow{2}{*}{ درونى نامربوط } \\
\hline$\cdot 1 \cdot \cdot 1$ & $\mid F / T \Lambda$ & $-\Delta \varphi / 9$. & بيرونى نامربوط & \\
\hline .191 & $19 / 90$ & $-r q / F \Delta$ & بيرونى نامربوط & بيرونى مربوط \\
\hline
\end{tabular}

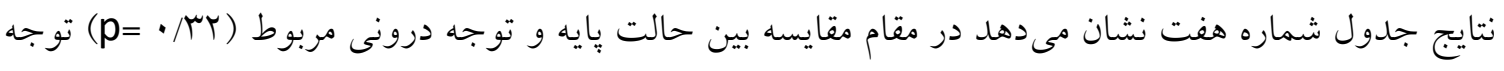

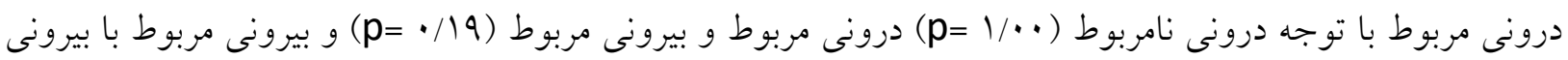

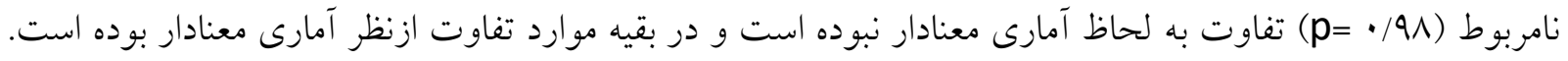

\section{بحث و نتيجه تيرى}

يزوهش حاضر باهدف مقايسه اثر توجه درونى /بيرونى و مربوط/نامربوط بر تغييرات جشم ساكن و دقت يرتاب بسكتباليستهاى ماهر انجام گرفت. با توجه به اطلاعات جداول دو الى هفت يافته هاى يُزوهش نشان داد ار ائه دستور العمل هاى توجهى بر دقت يرتاب آزاد بسكتبال و تغييرات جشم ساكن بسكتباليستهاى ماهر اثر گذار بوده است. نتايج حاكى از بهبود دقت يرتاب آزاد بسكتبال و افزايش طول دوره جشم ساكن در هر يكى از شرايط توجهى نسبت به شرايط پِيه بود. دراينارتباط وولف (rا ·Y)، معتقد است كه مربيان و متخصصان ورزشى مىتواند تنها با تغيير كلمات و عبارات دستور العملهاى كلامى خود بهعنوان يك قيد تكليف، توجه اجراكنندهها را بر جنبههاى خاصى از تكليف و مهارت در حال اجرا متمركز نموده و به دنبال آن عملكرد و ياد گيرى حركتى اجر اكنندگان را بهطور متفاوتى تحت تأثير قرار دهند(r). گروهى از تحقيقات بر مزاياى توجه بيرونى نسبت به توجه درونى در افراد مبتدى و ماهر تأكيددارند(ب, 0, اسا) ، در مقابل، كروه ديخرى از تحقيقات، بر مزاياى توجه مربوط به تكليف صرفنظر از درونى و يا بيرونى بودن آنها در افراد

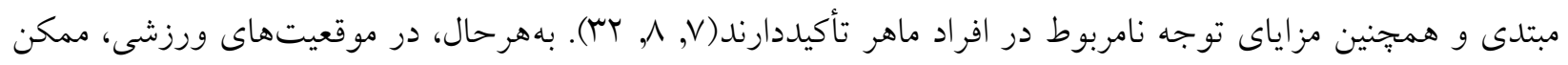
است يكى مربى، در حين ارائه راهبردهاى توجهى درونى و بيرونى به ورزشكار، بهطور همزمان، بر جنبههايى مرتبط با 
تكليف در حال اجرا و يا برخى از جنبههاى محيطى و يا نامربوط به تكليف در حال اجرا تأكيد داشته باشد(•(1) ، كه بتواند افزايش عملكرد و ياد كيرى را به دنبال داشته باشد. نتايج تحقيق حاضر نيز مؤيد اين مطلب است كه دستور العملهاى مختلف توجهى باعث افزايش دقت يرتاب آزاد بسكتبال و افزايش طول دوره جشم ساكن بسكتباليستهاى ماهر كرديد.

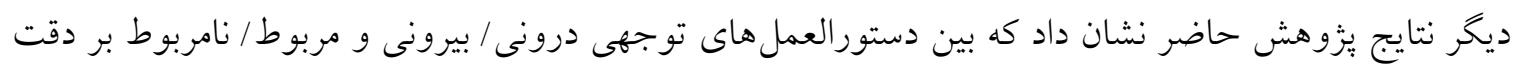

يرتاب آزاد بسكتباليستهاى ماهر تفاوت آمارى معنادارى وجود دارد. نتايج حاكى از بهتر بودن دقت يرتاب آزاد بسكتبال در شرايط كانون توجه بيرونى نامربوط نسبت به شرايط ديخر بود. نتايج اين يافته در دو بعد اهميت بررسى دارد. ابتدا

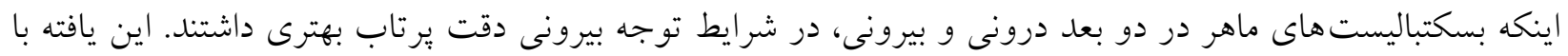

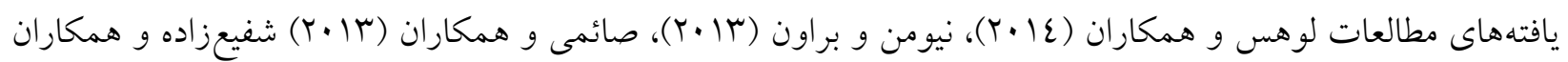

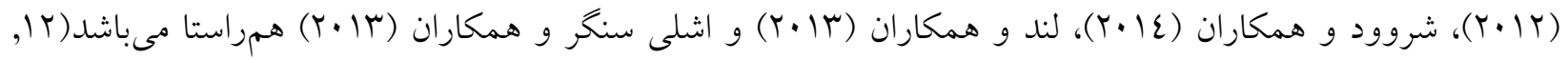

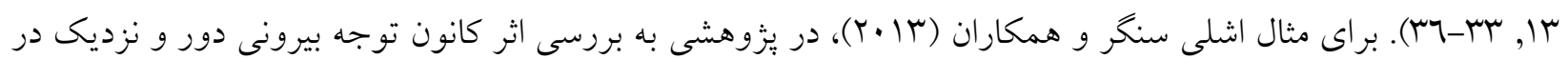
شرايط حضور و يا عدم حضور بينايى در يك تكليف بيخكرى برداختند. بدين منظور، 91 شركت كننده، تكليف بيخردى را تحت سه شرايط توجه بيرونى دور، توجه بيرونى نزديك و توجه درونى اجرا كردند. يافتهاى تحقيقى آنها نشان داد كه كانون توجه بيرونى دور صرفنظر از حضور و يا عدم حضور توجه بينايى، برتر از كانون توجه درونى مىباشد(Y).

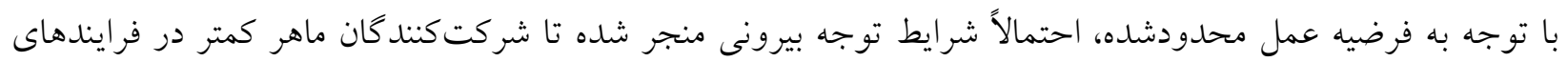
كنترل هشيارانه كه نيازمند ظرفيت بالاى حافظه كارى است، درگير شوند و بنابراين بيشتر از فرايندهاى كنترل خودكار بهر بردهاند، و بهتبع آن، عملكرد ماهرانهترى را از خود به نمايش كذاشتهاند (ع ())، همجنين با توجه به ديدكاه قيود محور، مى توان نتيجه گرفت، شركت كنند گان بزوهش حاضر، بهواسطه به كار گيرى راهبردهاى توجهى بيرونى، تو انستهاند، اطلاعات

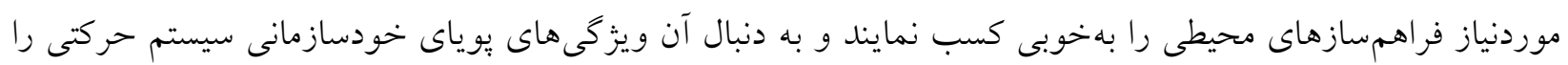
بهبود بخشيده و درنهايت منجر به بهبود عملكرد حركتى، خودكردند(10). بهعبارتديخر، معطوف كردن توجه بر اثرات حركت در محيط، بهواسطه جهت دادن بر فرايندهاى جستجوى فراهمسازهاى مربوط به اجراى تكليف برتاب آزاد بسكتبال، به اجراكنندها در جستجو و كشف اطلاعات ويزه محيطى موردنياز جهت توسعه جفت شدن ادراك/ عمل و خودسازمانى قيود اجراى تكليف، جهت داده و به دنبال آن، منجر به بهبود دقت ٍِرتاب آزاد آنها شده است(YV). دوم اينكه در بعد مربوط/ نامربوط، بسكتباليستهاى ماهر در شرايط نامربوط دقت يرتاب آزاد بهترى داشتند. بيلاك و همكاران (Y + (Y)، در تحقيق خود كه اثر توجه را بر مهارتهاى ضربه زدن به توبٍ كلف و مهارت ينالتى را كلف بازان و فوتباليستهاى مبتدى و ماهر بررسى كردند كه شركت كند كان در دو شرايط توجه مربوط به تكليف (توجه كردن به جوب و توبٌ كلف، يا توجه كردن به توبٌ فوتبال) و شرايط توجه نامربوط به تكليف (كوش كردن به نوار

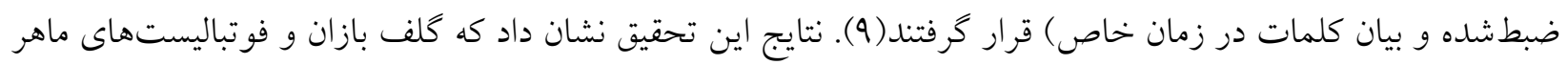
در شر ايط توجه مربوط به تكليف افت بيشترى داشتند، درصورتى كه فوتباليستهاى مبتدى در شرايط توجه مربوط، تكليف بئ بئ 
را بهتر اجرا كردند. علاوه بر اين، معين و همكاران (r/II) نيز نشان دادند افراد با سطح مهارت بايين در شرايط توجه نامربوط به تكليف و افراد با سطح مهارت بالا در شرايط توجه مربوط به تكليف، دجار انسداد شدند(^^). بنابراين مىتوان كفت احتمالاً افراد با سطح مهارت بايين از نشانههاى توجهى مربوط بيشتر سود مى برند و هرجهه سطح مهارت افراد بالاتر رود نشانهاى توجهى نامربوط اهميت بيشترى بيدا مى كنند(IV). با توجه به نظريه ارزيابى آشكار، افراد ماهر در شرايط راهبردهاى توجهى نامربوط به تكليف نسبت به شرايط

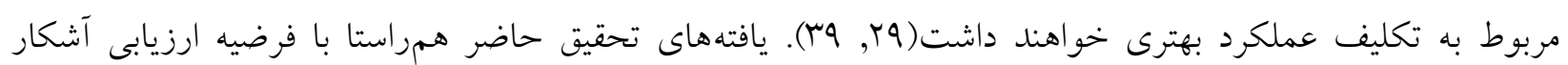
مى باشد. احتمالاً شر ايط توجه مربوط به تكليف منجر به دركير كردن شركت كنند كان، در كنترل هشيار انه و همجنين ارزيابى

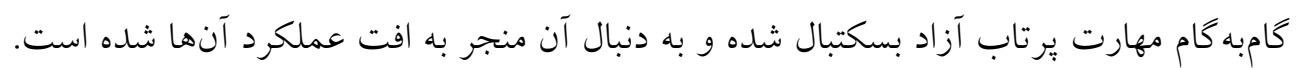

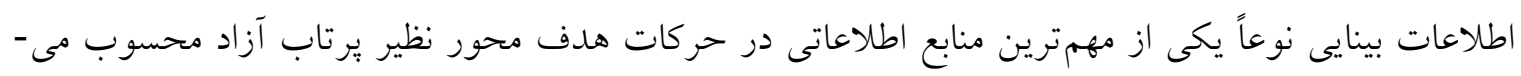
شوند(•ع) ، در باب نقش تعديل كننده اطلاعات بينايى در بروز مزاياى راهبردهاى توجهى بيرونى، رويكردى كه توسط

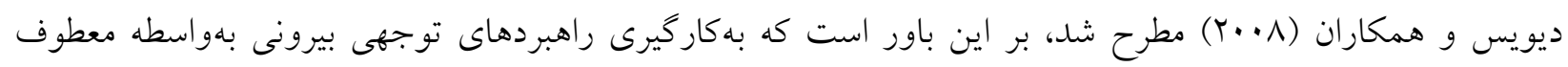

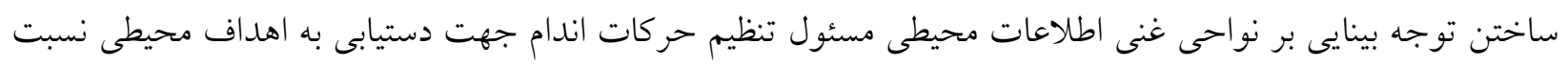

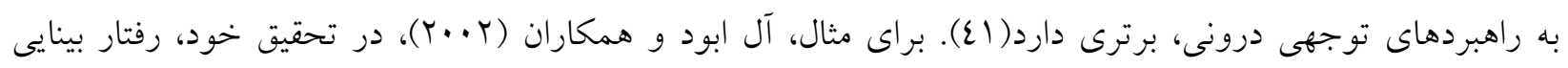
شركت كنند كانى را كه در حال ديدن يك فيلم ويدئويى شامل اجراى تكليف يرتاب آزاد بسكتبال توسط يكى فرد ماهر بردي بودند را موردبررسى قراردادند. قبل از ديدن فيلم ويدئويى، به شركتكنندكان دستورالعمل هايى جهت تمركز بر شكل حركات (توجهى درونى) و اثرات حركات در محيط (توجهى بيرونى) دادهشده بود، يافتهاى تحقيق آنها نشان داد گروه توجه بيرونى بهمراتب برتر از گروه توجه درونى بود، بهعلاوه، بررسى رفتار خيرگى بينايى نشان داد كه گروه توجه بيرونى، زمان بيشترى راصرف ديدن اطلاعات خارج از بدن كرده است، بنابراين، محققين نتيجه گرفتند تفاوت بين دو گروه توجه برهي درونى و بيرونى به دليل استفاده بيشتر گروه توجه بيرونى نسبت به توجه درونى، از اطلاعات بينايى مى باشد، بهعبارتديكر،

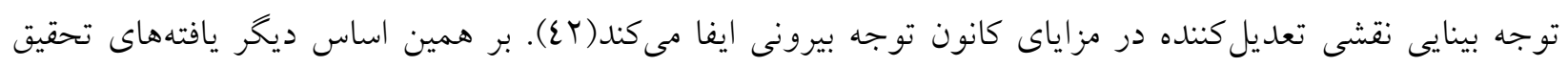
حاضر نشان داد كه بين دستور العمل هاى توجهى درونى / بيرونى و مربوط / نامربوط بر تغييرات جشم ساكن بسكتباليست-

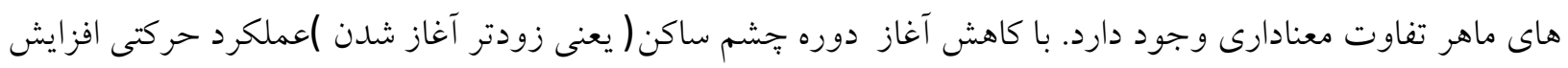
مى يايد. كاسر و همكاران( •(·r)، معتقدند كه شروع زودتر تشم ساكن باعث يردازش بهتر اطلاعات و توجه به نشانه هاى مربوط در تكاليف مى شود و در نتيجه باعث شروع پاسخ صحيح مى گردد(بع). هر تهه مدت دوره جشم ساكن طولانى تر باشد و ديرتر اين مدت اتمام يابد، عملكرد حركتى افزايش مى يابد. جشم ساكن به يِيش بينى عمل در كنترل

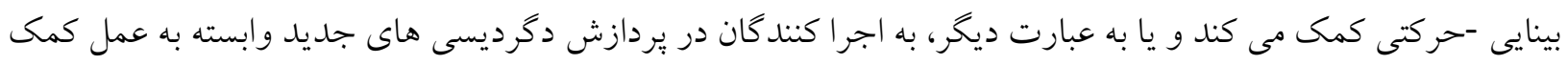

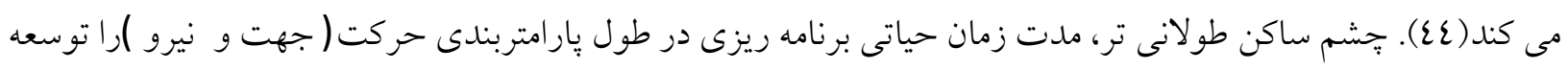

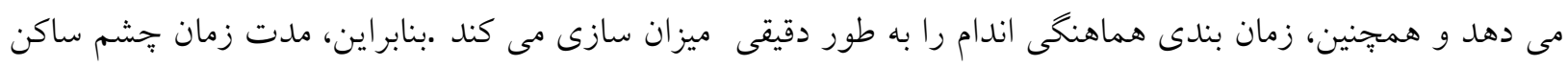


طولانى تر، براى سيستم كنترل حركتى اطلاعاتى درباره موقعيت هدف فراهم مى آورد و باعث مى شود كه كينماتيك حركت و الكوى فعاليت عضلات براى اجراى موفق مهارت مؤثر واقع شود( ع). از آن جا كه شروع جشم ساكن قبل از حركت آغاز مى شود و مدت زمان آن زمانى كه فرد اجرا كننده ماهر مى باشد، طولانى تر است، دوره جشم ساكن بازه زمانى را كه شبكه هاى عصبى در حين اجراى حركتى از قبل سازماندهى و كنترل مى شود، نشان مى دهد و اين اطلاعات

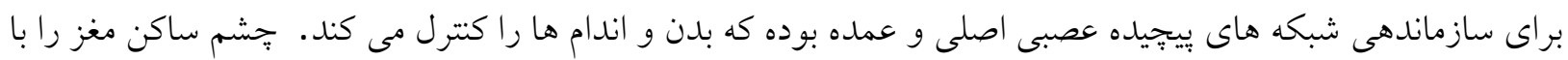
اطلاعات فضايى مطلوب مورد نياز عمل تغذيه مى كند كه به طور مؤثر سازماندهى، شروع و كنترل شود .هنگامى كه موقعيت، شروع، يايان و مدت زمان جشم ساكن همخى بهينه باشد، آن كاه عملكرد در بالاترين سطح است و زمانى كه يكى از اين موارد بهينه نباشد، اجرا دستخوش تغيير خواهد شد(1)). نتايج حاكى از طولانىتر بودن جشم ساكن شركتكنندكان در شرايط اتخاذ كانون توجه بيرونى نامربوط، نسبت به شرايط ديخر بود. اين يافته با نتايج رينهوف و و

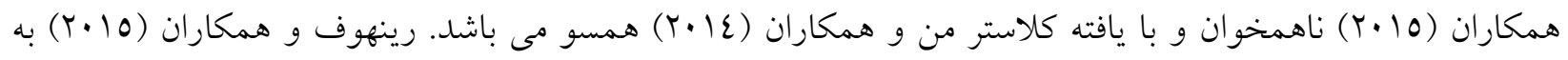
بررسى تعامل بين كانون توجه و جُشم ساكن در بسكتباليستها با سطوح متفاوت خبركى (ماهر، نيمه ماهر، مبتدى) يرداختند. شركت كنندكان در اين يزوهش بر اساس سطوح متفاوت خبركى به اجراى يرتاب آزاد بسكتبال تحت شرايط

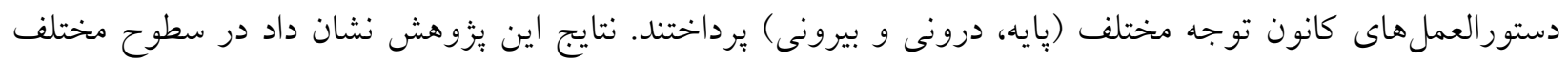
خبركى ميزان دقت يرتاب و دوره جشم ساكن تحت شر ايط كانون توجه بيرونى كاهش مى يافت( كلاستر من و همكاران (ع) • (Y)، همخوان است كه در شرايط توجه بيرونى، جشم ساكن طولانى تر بود(YN). مدل شناختى - عصبى براى توجيه كاركرد جُشم ساكن براى حفظ كنترل توجه بهينه توسط كور بتا، ياتل و شالمن

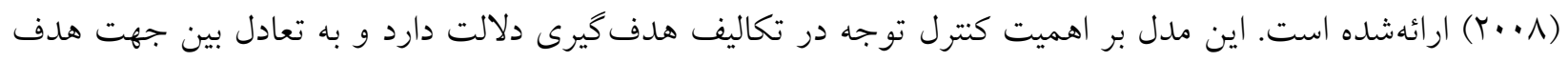
بين دو مسير بالا به پِايين (يشتى) و يايين به بالا (شكمى) حساس است. در مسير بالا به پايين سيستم توجهى هدف محور

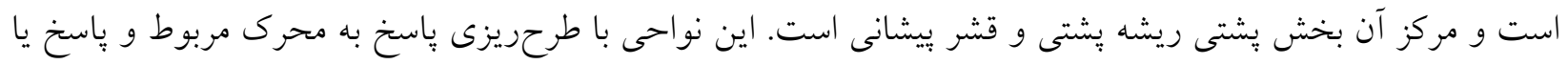

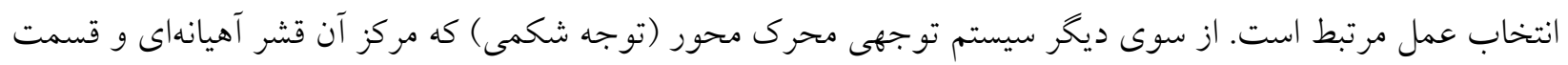
شكمى قشر بيشانى است، در طول تشخيص محركهاى برجسته و ناخواسته دركير است و حلقههاى توجه بالا به بإيين را مى شكند(^)). بر اين اساس ويكرز نيز مطرح مى كند كه دوره طولانى جشم ساكن ممكن است به اجر اكننده اجازه دهد

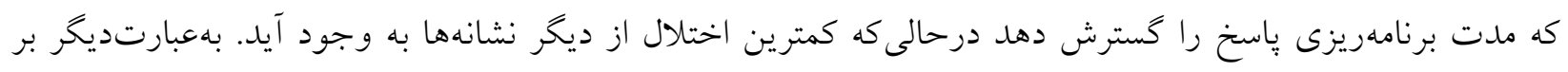

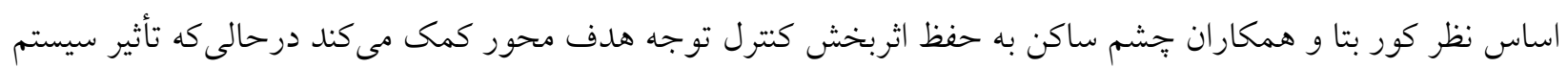

$$
\text { كنترل توجه محور را كاهش مى دهد (19). }
$$

با توجه به اثر كذارى دستور العمل هاى توجهى بر دقت يرتاب آزاد بسكتبال و بر طول دوره جشمم ساكن، به مربيان

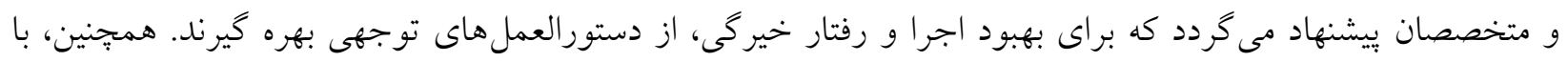




$$
\text { منابع استفاده از اين راهبرا و دقت بهتر و طول دوره جشم ساكن بيشتر بسكتباليست هاى ماهر در شرايط اتخاذ توجه بيرونى نامربوط }
$$

1. Abbasi A, Sadeghi H, BerenjianTabrizi H, B, K, GhasemiRad A. Effects of aquatic balance training and detraining on neuromuscular performance and balance in healthy middle aged male Koumesh. 2011;13(3):345-53(in persian).

2. Wulf G. Attentional focus and motor learning: A review of 10 years of research. E-journal Bewegung und Training. 2007;1(2-3):1-11.

3. Wulf G. Attentional focus and motor learning: a review of 15 years. International Review of Sport and Exercise Psychology. 2013;6(1):77-104.

4. Dan DA, Axelerad DA, Mirela D, Barbu A, Carciumaru N. Effects of physical recuperation in patients with multiple sclerosis. Ovidius University Annals, Series Physical Education and Sport/Science, Movement and Health. 2009;9(2):161-4.

5. Wiggins MS, Rader E, Erdmann JB. Exercise Benefits for Multiple Sclerosis Participant: Case Study. International Journal of MS Care. 2007;9(3):126-30.

6. Clark M, Fater D, Reuteman P. Core (trunk) stabilization and its importance for closed kinetic chain rehabilitation. Orthopaedic Physical Therapy Clinics of North America. 2000;9(2):119-36.

7. OMINO K, HAYASHI Y. Preparation of dynamic posture and occurrence of low back pain. Ergonomics. 1992;35(5-6):693-707.

8. Castaneda B, Gray R. Effects of focus of attention on baseball batting performance in players of differing skill levels. Journal of Sport and Exercise Psychology. 2007;29(1):60.

9. Beilock SL, Carr TH, MacMahon C, Starkes JL. When paying attention becomes counterproductive: impact of divided versus skill-focused attention on novice and experienced performance of sensorimotor skills. J Exp Psychol Appl. 2002;8(1):6.

10. Russell R, Porter J, Campbell O. An external skill focus is necessary to enhance performance. Journal of Motor Learning and Development. 2014;2(2):37-46.

11. Aslankhani M, Shams A, Shamsipour P. Mental, physical and mixed practice effects on elderly static and dynamic balance Iranian Journal of Ageing. 2008;3(9):9-22(in persian.(

12. Saemi E, Porter J, Wulf G, Ghotbi-Varzaneh A, Bakhtiari S. Adopting an external focus of attention facilitates motor learning in children with attention deficit hyperactivity disorder. Kineziologija. 2013;45(2):179-85.

13. Shafizadeh M, Platt GK, Mohammadi B. Effects of different focus of attention rehabilitative training on gait performance in Multiple Sclerosis patients. J Bodyw Mov Ther. 2013;17(1):28-34.

14. Wulf $\mathrm{G}, \mathrm{McNevin} \mathrm{N}$, Shea $\mathrm{CH}$. The automaticity of complex motor skill learning as a function of attentional focus. The Quarterly Journal of Experimental Psychology: Section A. 2001;54(4):1143-54.

15. Davids K. Increases in jump-and-reach height through an external focus of attention: A commentary. International Journal of Sports Science \& Coaching. 2007;2(3):285-8.

16. Beilock SL, Bertenthal BI, McCoy AM, Carr TH. Haste does not always make waste: Expertise, direction of attention, and speed versus accuracy in performing sensorimotor skills. Psychonomic bulletin \& review. 2004;11(2):373-9.

17. Gray R. Attending to the execution of a complex sensorimotor skill: expertise differences, choking, and slumps. J Exp Psychol Appl. 2004;10(1):42. 
18. Keeley TJ, Fox KR. The impact of physical activity and fitness on academic achievement and cognitive performance in children. International Review of Sport and Exercise Psychology. 2009;2(2):198-214.

19. Vine SJ, Moore LJ, Wilson MR. Quiet eye training: The acquisition, refinement and resilient performance of targeting skills. European Journal of Sport Science. 2014;14(sup1):S235-S42.

20. Rydeard R, Leger A, Smith D. Pilates-based therapeutic exercise: effect on subjects with nonspecific chronic low back pain and functional disability: a randomized controlled trial. J Orthop Sports Phys Ther. 2006;36(7):472-84.

21. Wilson MR, Causer J, Vickers JN. The quiet eye as a characteristic of expertise. Routledge handbook of sport expertise. 2015:22.

22. McNevin $\mathrm{NH}$, Shea $\mathrm{CH}$, Wulf $\mathrm{G}$. Increasing the distance of an external focus of attention enhances learning. Psychol Res. 2003;67(1):22-9.

23. Hillman $\mathrm{CH}$, Erickson $\mathrm{KI}$, Kramer AF. Be smart, exercise your heart: exercise effects on brain and cognition. Nature reviews neuroscience. 2008;9(1):58.

24. Azimzadeh E, Aslankhani $M$, Shojaei $M$, Salavati $M$. The influence of perturbation and nonperturbation balance training program on static and dynamic balance in elderly women Motor Behavior. 2013;5(13):95-108.

25. Saki B, Paydar S, Amraei Z, Abarghuei A. The effect of garlic supplementation on aerobic performance in non-athlete men. Iranian Journal of Nutrition Sciences \& Food Technology. 2015;10(2):115-20.

26. S s, khayambashi K, Gh G, Falah A, Sakhavat E. Effects of Selected Core Stabilization Exercise Protocol on Pain and

Functional Disability in Subjects with Chronic Non-specific Low Back Pain J Res Rehabil Sci 2014;10(1):5666 (in persian).

27. Stuchlik A. Dynamic learning and memory, synaptic plasticity and neurogenesis: an update. Front Behav Neurosci. 2014;8:106.

28. Klostermann A, Kredel R, Hossner E-J. On the interaction of attentional focus and gaze: the quiet eye inhibits focus-related performance decrements. Journal of Sport and Exercise Psychology. 2014;36(4):392-400.

29. Beilock SL, Carr TH. On the fragility of skilled performance: what governs choking under pressure? J Exp Psychol Gen. 2001;130(4):701.

30. Fahimi H, Ghotbi-Varzaneh A, Yazdani M. The Relationship between Quiet Eye and Motor Performance in Children with Developmental Coordination Disorder. Research Rehabilitation Scinces. 2016;12(6):35561 (in persian.l

31. Lohse KR, Sherwood DE, Healy AF. How changing the focus of attention affects performance, kinematics, and electromyography in dart throwing. Human Movement Science. 2010;29(4):542-55.

32. Beilock SL, Holt LE. Embodied Preference Judgments Can Likeability Be Driven by the Motor System? Psychol Sci. 2007;18(1)7-51.

33. Lohse KR, Sherwood DE, Healy AF. On the advantage of an external focus of attention: A benefit to learning or performance? Human movement science. 2014;33:120-34.

34. Neumann DL, Brown J. The effect of attentional focus strategy on physiological and motor performance during a sit-up exercise. Journal of Psychophysiology. 2013.

35. Land WM, Tenenbaum G, Ward P, Marquardt C. Examination of visual information as a mediator of external focus benefits. Journal of Sport and Exercise Psychology. 2013;35(3):250-9.

36. Schlesinger $M$, Porter J, Russell R. An external focus of attention enhances manual tracking performance. 2013.

37. Wulf G, Zachry T, Granados C, Dufek JS. Increases in jump-and-reach height through an external focus of attention. International Journal of Sports Science \& Coaching. 2007;2(3):275-84. 
38. moeen F, ZAHEDI h, Meshkati Z. The effect of attention on service valiball service accuracy unde psychological pressure. Research on sports management and motor behavior. 2015;1(21):49-56.( in persian).

39. Baumeister RF. Choking under pressure: self-consciousness and paradoxical effects of incentives on skillful performance. J Pers Soc Psychol. 1984;46(3):610.

40. Carlton LG. Visual processing time and the control of movement .Advances in psychology. 85: Elsevier; 1992. p. 3-31.

41. Davids K, Button C, Bennett S. Dynamics of skill acquisition: A constraints-led approach: Human Kinetics. Google Scholar. 2008.

42. Al-Abood SA, Bennett SJ, Hernandez FM, Ashford D, Davids K. Effect of verbal instructions and image size on visual search strategies in basketball free throw shooting. J Sports Sci. 2002;20(3):271-8.

43. Causer J, Bennett SJ, Holmes PS, Janelle CM, Williams AM. Quiet eye duration and gun motion in elite shotgun shooting. Med Sci Sports Exerc. 2010;42(8):1599-608.

44. Flanagan JR, Vetter P, Johansson RS, Wolpert DM. Prediction precedes control in motor learning. Curr Biol. 2003;13(2):146-50.

45. Alder D, Ford PR, Causer J, Williams AM. The coupling between gaze behavior and opponent kinematics during anticipation of badminton shots. Human movement science. 2014;37:167-79.

46. Vickers JN. The quiet eye: origins, controversies, and future directions. Kinesiology Review. 2016;5(2):119-28.

47. Rienhoff R, Fischer L, Strauss B, Baker J, Schorer J. Focus of attention influences quiet-eye behavior: An exploratory investigation of different skill levels in female basketball players. Sport, Exercise, and Performance Psychology. 2015;4(1):62.

48. Corbetta M, Patel G, Shulman GL .The reorienting system of the human brain: from environment to theory of mind. Neuron. 2008;58(3):306-24. 